\title{
Notes on the vocalizations of Blue Fantail (Rhipidura superciliaris)
}

Peter Boesman

In the following we briefly analyze and compare voice of the three races of Blue Fantail (Rhipidura superciliaris). We also try to quantify the extent of any vocal differences using the criteria proposed by Tobias et al. (2010), as a support for taxonomic review.

We have made use of sound recordings available on-line from Xeno Canto (XC) and Macaulay Library (ML), and we received additional recordings of samarensis from Rob Hutchinson.

A comparison of voice per race, illustrated with sonograms:

samaransis

song

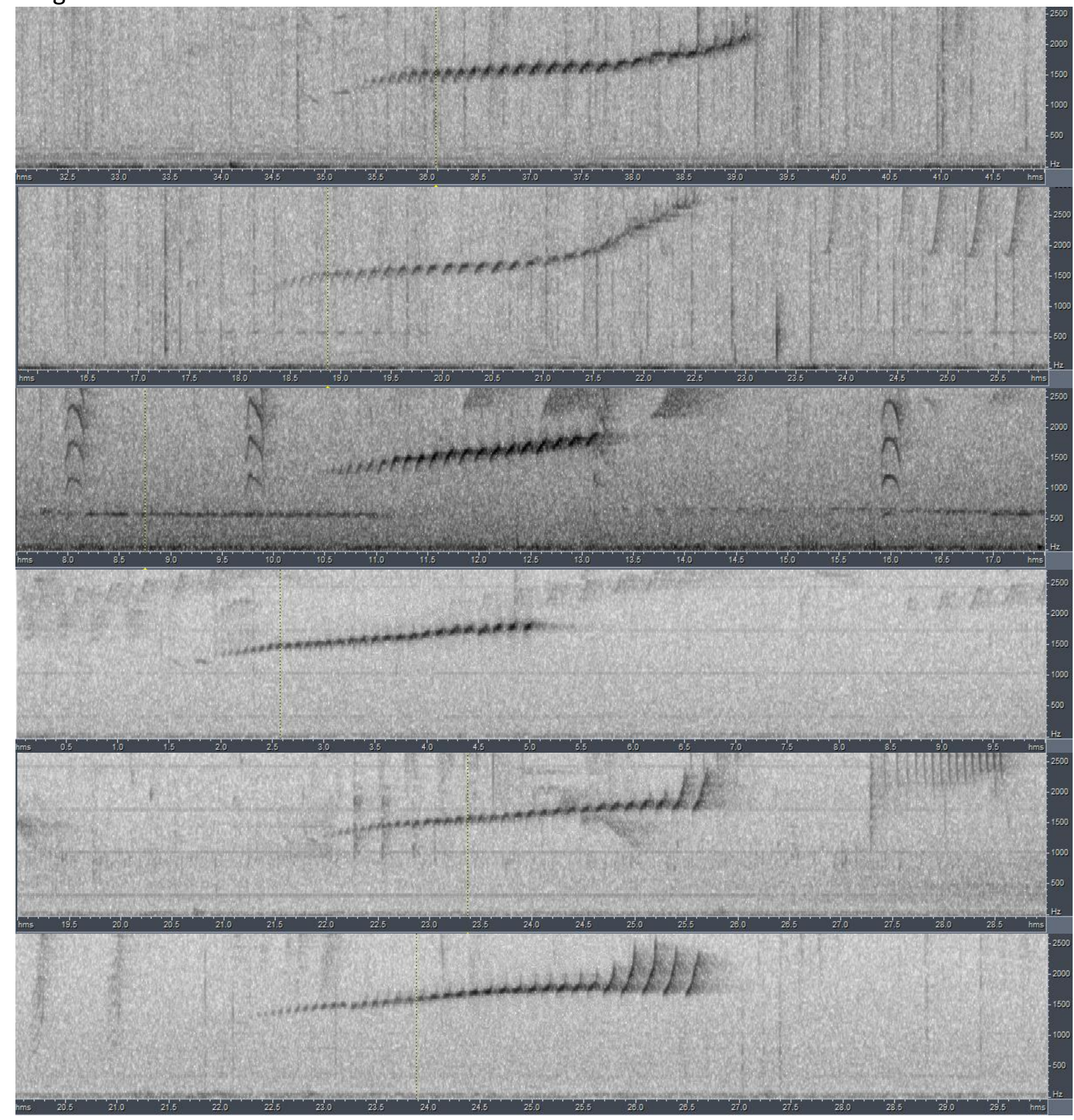




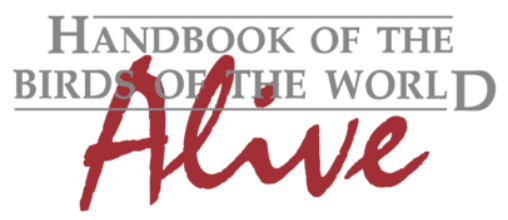

\section{ORNITHOLOGICAL NOTES}

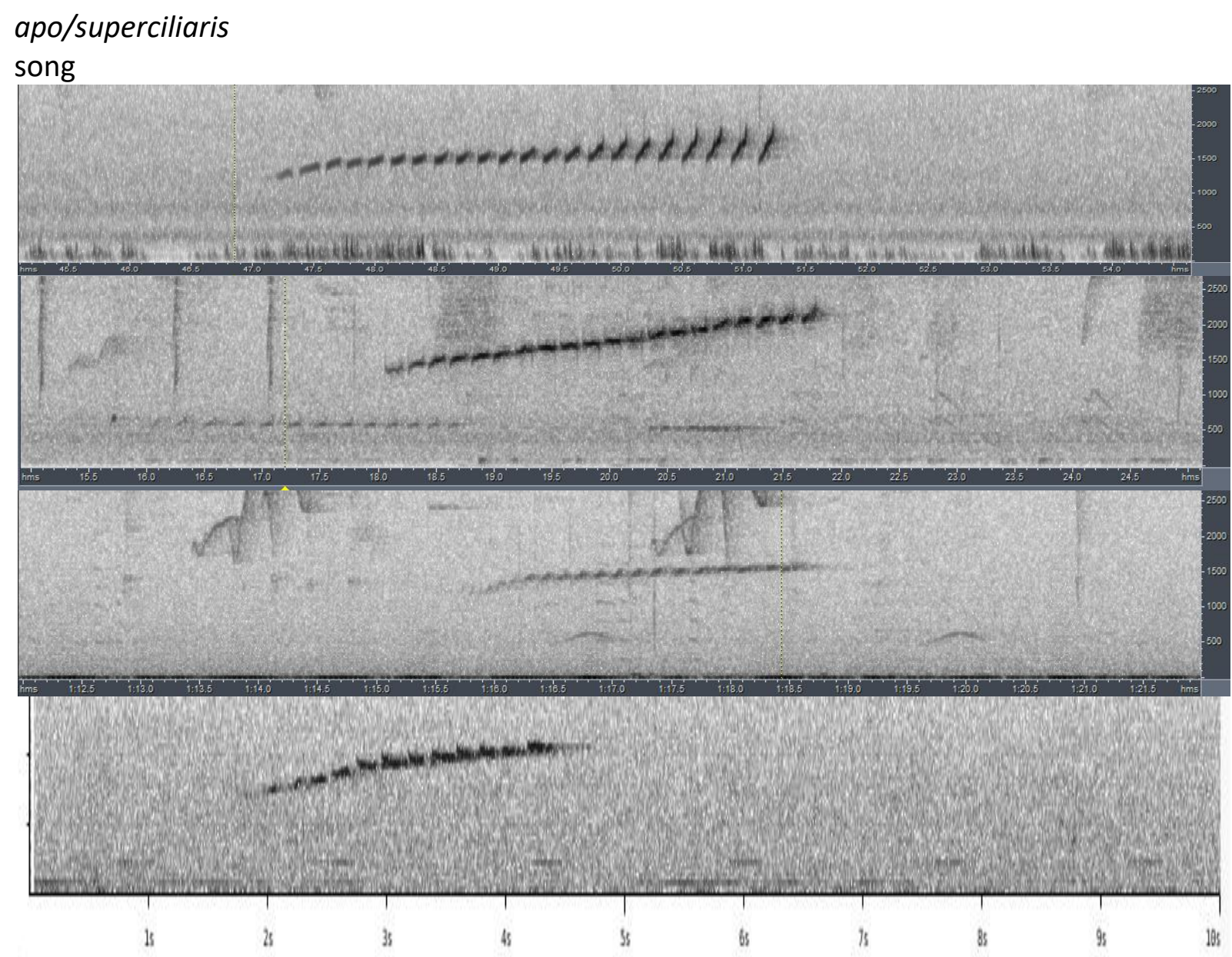

Song of both groups is a series of steadily rising notes, but there are clear differences: samarensis typically initiates at a much higher pace (c 10-13 notes/s vs typically 5 notes/s, occasionally up to 9 notes/s for apo/superciliaris), apo/superciliaris thus has a much more even pace over the entire song phrase. As a result, the total number of notes per song phrase in samarensis is also noticeably higher: 21-35 notes vs 12-22 notes in apo/superciliaris.

Comparison of calls reveal also a significant difference:

samarensis $(\mathrm{n}=5)$

Call is a fairly long, raspy, nasal 'rreh' or 'neh'
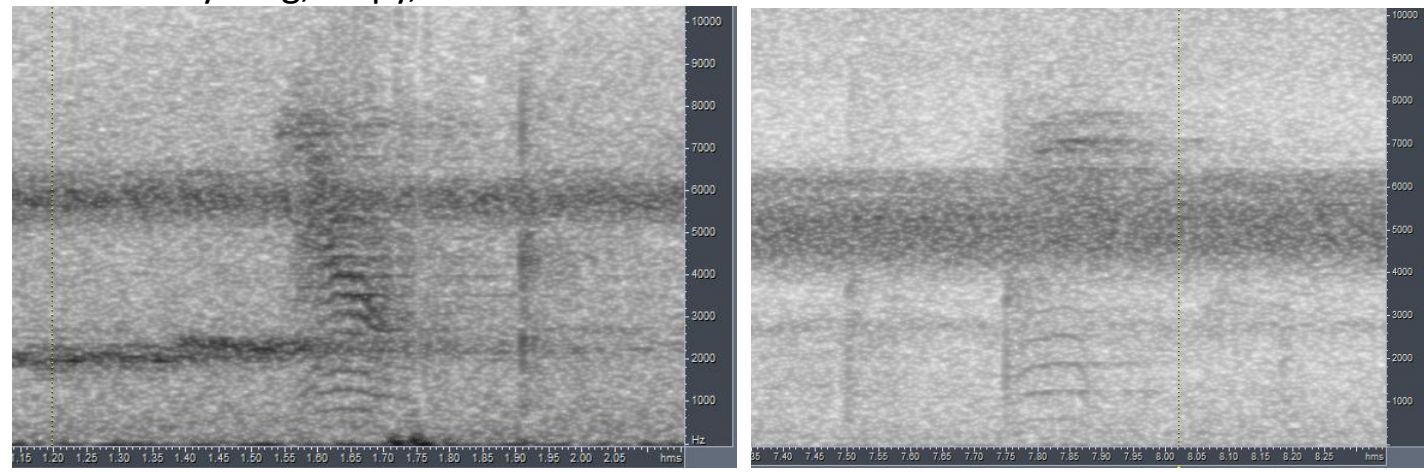


\section{HANDBOOK OF THE Alve}

\section{ORNITHOLOGICAL NOTES}
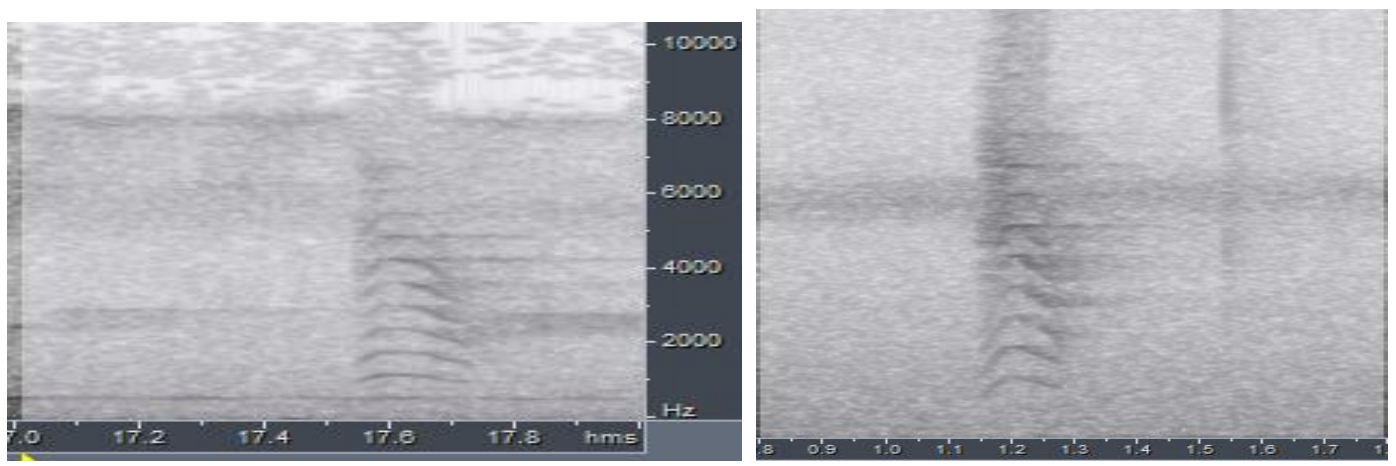

Note length $0.1-0.16 \mathrm{~s}$, mainly flat pitch, end frequency $<1000 \mathrm{~Hz}$

apo/superciliaris $(n=10+)$

Call is a short, crisp metallic 'wick!'

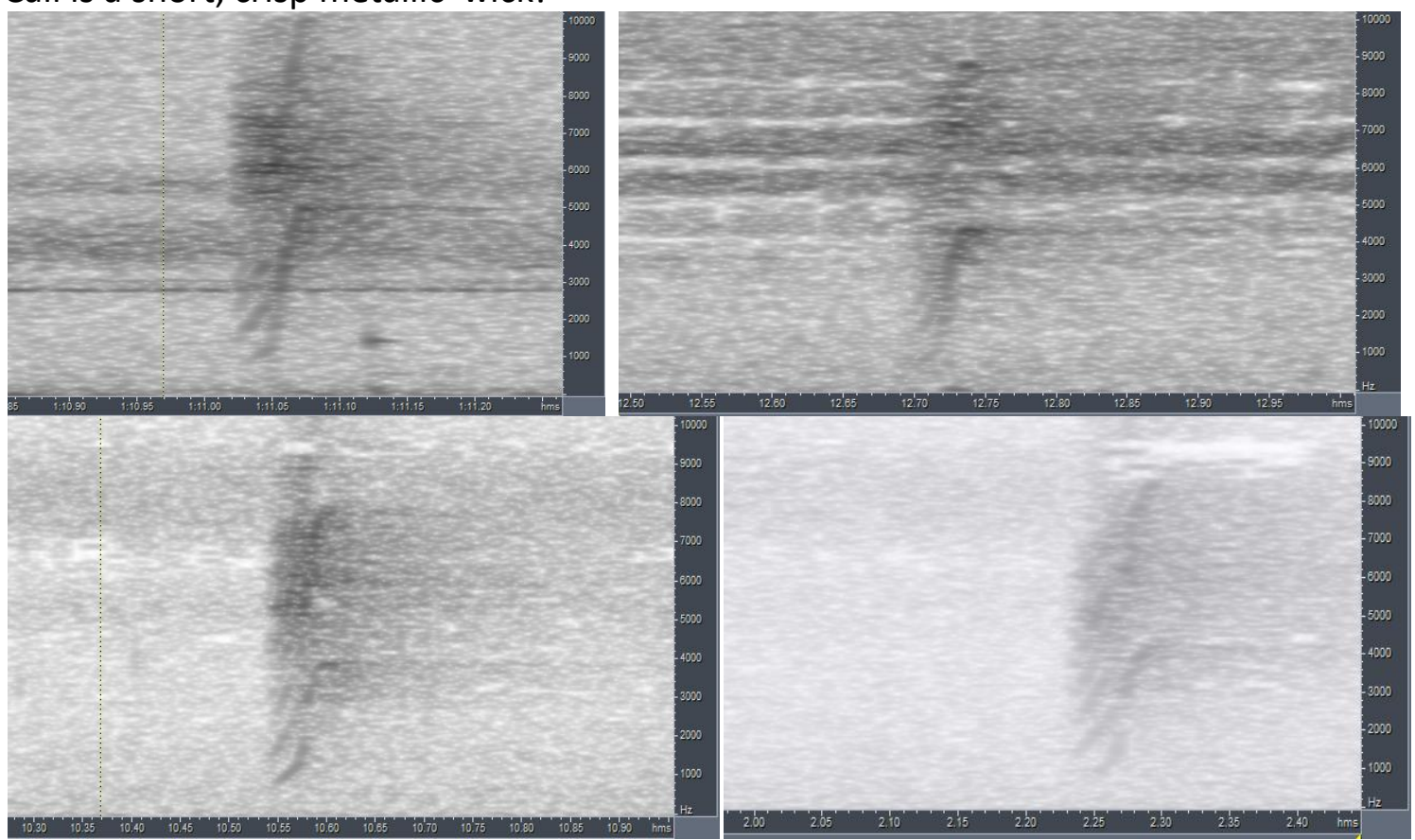

Note length $0.04-0.06 \mathrm{~s}$, rising pitch, end frequency $>1500 \mathrm{~Hz}$

Voice of samarensis is thus quite different, which can be quantified as follows:

Song starts much faster-paced (score 3) and has more notes (score 2-3). Call is longer (score 3), nasal and overslurred (vs crisp and upslurred), ending at much lower frequency (score 3). Application of Tobias criteria would lead to a total vocal score of about 5-6.

This note was finalized on 16th March 2016, using sound recordings available on-line at that moment. We would like to thank in particular the sound recordists who placed their recordings for this species on XC and ML: Desmond Allen, Tomas Carlberg, Peter Hosner, Robert Kennedy, Ben King, Frank Lambert, Mark Todd; and Rob Hutchinson for providing additional recordings. 


\section{References}

Tobias, J.A., Seddon, N., Spottiswoode, C.N., Pilgrim, J.D., Fishpool, L.D.C. \& Collar, N.J. (2010). Quantitative criteria for species delimitation. Ibis 152(4): 724-746.

\section{Recommended citation}

Boesman, P. (2016). Notes on the vocalizations of Blue Fantail (Rhipidura superciliaris). HBW Alive Ornithological Note 434. In: Handbook of the Birds of the World Alive. Lynx Edicions, Barcelona. (retrieved from http://www.hbw.com/node/1275619 on 8 December 2016). 